\title{
PENGARUH MODEL PEMBELAJARAN BERBASIS MASALAH TERHADAP KEMAMPUAN PEMAHAMAN KONSEP MATEMATIS SISWA KELAS VIII SMP KESEHATAN MANDONGA
}

\author{
Nurdin Hamid ${ }^{1)}$, rvyaty $^{2)}$, Ikman $^{3)}$ \\ ${ }^{1)}$ Alumni Jurusan Pendidikan Matematika, ${ }^{2,3)}$ Dosen Jurusan Pemdidikan Matematika \\ FKIP Universitas Halu Oleo Email: nurdinhamidsalangga94@ gmail.com ${ }^{1)}$; \\ arvyaty@gmail.com ${ }^{2}$; ikman_fkipmat@yahoo.com³).
}

\begin{abstract}
Abstrak
Penelitian ini dilatarbelakangi oleh rendahnya pemahaman konsep matematis siswa dalam pelajaran matematika. Populasi penelitian adalah seluruh siswa kelas VIII SMP Kehatan Mandonga dan dipilih sampel sebanyak 2 kelas. Pengambilan sampel menggunakan teknik sensus/sampel total. Teknik pengumpulan data dengan pemberian instrumen penelitian berupa lembar observasi dan pemahaman konsep matematis siswa berbentuk soal uraian. Berdasarkan hasil analisis data dan pembahasan diperoleh kesimpulan: (1) proses pembelajaran matematika dengan menggunakan model pembelajaran berbasis masalah pada siswa kelas eksperimen tergolong baik, (2) pemahaman konsep matematis siswa kelas VIII SMP kesehatan mandonga yang diajar menggunakan model pembelajaran berbasis masalah pada SPLDV memiliki nilai rata-rata 55,88 dan varians 170,41, (3) Pemahaman konsep matematis siswa kelas VIII SMP kesehatan mandonga yang diajar menggunakan model pembelajaran konvensional pada materi SPLDV memiliki nilai rata-rata 45,91 dan varians 286,65; (4) Ada pengaruh yang signifikan penggunaan model pembelajaran berbasis masalah terhadap kemampuan pemahamn konsep matematis siswa kelas VIII SMP Kesehatan Mandonga.
\end{abstract}

Kata kunci: pembelajaran berbasis masalah, pemahaman konsep matematis.

\section{THE EFFECT OF PROBLEM BASED LEARNING ON UNDERSTANDING OF MATHEMATIC CONCEPTS STUDENT CLASS VIII SMP KESEHATAN MANDONGA}

\begin{abstract}
This research is motivated by low students' understanding of mathematic concepts ability for mathematic learning. The study population was all students of class VIII of SMP Kesehatan Mandonga and selected samples of 2 classes. Sampling is done by census technique/total sample. Technique of data collecting is done by observation sheet and test understanding of mathematic concepts ability in essay form. Based on the results of data analysis and discussion, it can be concluded that: (1) the process of learning implementation by applying PBM on experiment class is good, (2) understanding of mathematic concepts ability of grade VIII students of SMP Kesehatan Mandonga for the class which is taught by using PBM on SPLDV has a mean value of 55,88 and variance of 170,41 by good category, (3) understanding of mathematic concepts ability of grade VIII students of SMP Kesehatan Mandonga for the class which is taught by using conventional learning model on SPLDV has a mean value of 45,91 and variance of 286,65 by sufficiently category, (4) there is significant influence of PBM to student's understanding of mathematic concepts class VIII SMP Kesehatan Mandonga.
\end{abstract}

Keywords: problem based learning, understanding of mathematic concepts. 


\section{Pendahuluan}

Pendidikan pada dasarnya merupakan hal yang penting yang harus dimiliki setiap manusia, dimana pendidikan tersebut, mampu memberikan pandangan setiap orang bahwa seseorang yang berpendidikan memiliki kemampuan yang baik disbanding dengan orang awam ini sejalan dengan pendapat Sagala (2014: 1), pendidikan adalah segala situasi hidup yang mempengaruhi pertumbuhan individu sebagai pengalaman belajar yang berlangsung dalam segala lingkungan dan sepanjang hidup.Dalam arti sempit pendidikan adalah pengajaran yang diselenggarakan umumnya di sekolah sebagai lembaga pendidikan formal.

Menurut Departemen Pendidikan Nasional (Depdiknas) dalam Kesumawati (2008: 2301) mengungkapkan bahwa, pemahaman konsep merupakan salah satu kecakapan atau kemahiran matematika yang diharapkan dapat tercapai dalam belajar matematika yaitu dengan menunjukkan pemahaman konsep matematika yang dipelajarinya, menjelaskan keterkaitan antar konsep dan mengaplikasikan konsep atau algoritma secara luwes, akurat, efisien, dan tepat dalam pemecahan masalah. Pemahaman terhadap suatu konsep sangat penting, karena apabila siswa menguasai konsep materi prasyarat maka siswa akan mudah untuk memahami konsep materi selanjutnya. Selain itu siswa yang menguasai konsep dapat mengidentifikasi dan mengerjakan soal yang lebih bervariasi. Oleh karena itu, guru memerlukan rancangan pembelajaran yang mampu membantu peningkatan pemahaman konsep siswa terhadap suatu materi dalam mata pelajaran matematika.

Salah satu mata pelajaran wajib di tingkat SMP adalah matematika. Matematika memerlukan pemahaman konsep, penalaran logis dan berfikir tingkat tinggi. Para siswa perlu memahami konsep dan menerapkannya dalam kehidupan sehari-hari. Masalah yang dihadapi para siswa dalam mata pelajaran matematika adalah sulit memahami konsep materi dengan benar. Siswa juga beranggapan bahwa mata pelajaran matematika itu sangat sulit untuk dipelajari.

Rendahnya pemahaman konsep matematis siswa kelas VIII SMP Kesehatan Mandonga disebabkan oleh banyak faktor, antara lain; faktor guru, materi, siswa, kurikulum, biaya, saraprasarana serta faktor lingkungan yang mempengaruhi dalam proses pembelajaran matematika. Dari sekian faktor yang ada secara teori diasumsikan menjadi penyebab rendahnya pemahaman konsep matematis siswa adalah faktor penggunaan model pembelajaran yang kurang bervariasi. Selama ini, guru telah berusaha seoptimal mungkin dalam membuat suasana edukatif dalam proses pembelajaran. Memperhatikan asumsi tersebut, maka perlu adanya usaha untuk meningkatkan pemahaman konsep matematis siswa kelas VIII SMP Kesehatan Mandonga dengan menggunakan model pembelajaran yang lebih bervariatif.

Menurut

Jihad

(2012:

mengemukakan bahwa belajar adalah kegiatan berproses dan merupakan unsur yang sangat fundamental dalam penyelengaraan jenis dan jenjang pendidikan, hal ini berarti keberhasilan pencapaian tujuan pendidikan sangat bergantung pada keberhasilan proses belajar siswa disekolah dan lingkungan sekitarnya.

Belajar bukan hanya mengamati, tetapi juga bisa dilakukan dengan proses melihat, mendengar, bahkan belajar melalui berbagai pengalaman yang dilaluinya baik dalam jenjang pendidikan maupun alam sekitar. Menurut Sagala (2014: 13) mengemukakan bahwa belajar merupakan tindakan dan perilaku siswa yang kompleks sebagai tindakan belajar hanya dialami oleh siswa sendiri. Tingkah laku siswa berbeda-beda, kepribadian berbeda, serta keingintahuan yang beragam. Sehingga sebagai pendidik harus memahami siswa baik di sekolah dan lingkungan sekitarnya. Hal ini senada dengan menurut Rusman (2014: 1), belajar pada hakikatnya adalah proses interaksi terhadap semua situasi yang ada disekitar individu. Belajar dapat dipandang sebagai proses yang diarahkan kepada tujuan dan proses berbuat melalui berbagai pengalaman.

Kegiatan pembelajaran dilakukan oleh dua pelaku, yaitu guru dan siswa. Guru bertindak sebagai pendidik sedangkan siswa sebagai pelaku belajar. Menurut Rusman (2014: 1), Pembelajaran merupakan suatu sistem, yang terdiri atas berbagai komponen yang saling berhubungan satu dengan yang lain. Komponen tersebut meliputi: tujuan, materi, metode, dan evaluasi. Selain itu, menurut Sagala (2014: 61) mengemukakan bahwa pembelajaran ialah membelajarkan siswa menggunakan asas pendidikan maupun teori belajar merupakan penentu utama keberhasilan pendidikan. 
Menurut Jihad (2012: 11), pembelajaran merupakan suatu proses yang terdiri dari kombinasi dua aspek, yaitu: belajar tertuju kepada apa yang harus dilakukan oleh siswa, mengajar berorientasi pada apa yang harus dilakukan oleh guru sebagai pemberi pelajaran.

Pembelajaran matematika adalah proses interaksi antara guru dan siswa yang melibatkan pengembangan pola berfikir dan mengolah logika pada suatu lingkungan belajar yang sengaja diciptakan oleh guru dengan berbagai metode agar program belajar matematika tumbuh dan berkembang secara optimal dan siswa dapat melakukan kegiatan belajar secara efektif dan efisien. Ini sejalan dengan pendapat Jihad (2012: 11) yang mengatakan bahwa pembelajaran merupakan proses yang terdiri dari kombinasi dua aspek yaitu belajar tertuju apa yang harus dilakukan oleh siswa, mengajar berorientasi pada apa yang harus dilakukan guru sebagai pemberi pembelajaran.

Selain interaksi yang baik antara guru dan siswa tersebut, faktor lain yang menentukan keberhasilan pembelajaran matematika adalah bahan ajar yang digunakan dalam proses pembelajaran tersebut. Berdasarkan uraian sebelumnya, dapat disimpulkan bahwa pembelajaran matematika merupakan suatu proses pengajaran yang membutuhkan kerja sama antara guru dan siswa agar pembelajaran tentang matematika terlaksana dengan efektif.

Menurut Taufiq dalam Fathurrohman (2015: 113) pembelajaran berbasis masalahadalah suatu model pembelajaran yang melibatkan peserta didik untuk memecahkan suatu masalah melalui tahap-tahap metode ilmiah sehingga peserta didik dapat mempelajari pengetahuan yang berhubungan dengan masalah tersebut dan sekaligus memiliki keterampilan untuk memecahkan masalah. Sedangkan, menurut Tan dalam Rusman (2014:232) menyatakan bahwa pembelajaran berbasis masalah merupakan penggunaan berbagai macam kecerdasan yang diperlukan untuk melakukan konfrontasi terhadap tantangan dunia nyata, kemampuan unutk menghadapi segala sesuatu yang baru dan kompleksitas.

Pusat pembelajaran dalam model pembelajaran berbasis masalah adalah peserta didik (student-centered), sementara guru berperan sebagai fasilitator yang memfasilitasi peserta didik untuk secara aktif menyelesaikan masalah dan membangun pengetahuannya secara berpasangan atau berkelompok. Peranan guru dalam model pembelajaran berbasis masalah adalah menyajikan masalah, mengajukan pertanyaan dan memfasilitasi penyelidikan dan dialog. Lebih penting lagi adalah guru melakukan scaffolding (Fathurrohman, 2015: 115).

Rusman (2014: 232) mengemukakan karakteristik pembelajaran berbasis masalah adalah sebagai berikut: a) permasalahan menjadi starting point dalam belajar; b) permasalahan yang diangkat adalah permasalahan yang ada di dunia nyata yang tidak terstruktur; c) permasalahan membutuhkan perspektif ganda (multiple perspective); d) permasalahan, menantang pengetahuan yang dimiliki oleh siswa, sikap, dan kompetensi yang kemudian membutuhkan identifikasi kebutuhan belajar dan bidang baru dalam belajar; e) belajar pengarahan diri menjadi hal yang utama; f) pemanfaatan sumber pengetahuan yang beragam, penggunaannya, dan evaluasi sumber informasi merupakan proses yang esensial dalam PBM; g) belajar adalah kolaboratif, komunikasi, dan kooperatif; h) pengembangan keterampilan inquiry dan pemecahan masalah sama pentingnya dengan penguasaan isi pengetahuan untuk mencari solusi dari sebuah permasalahan; i) keterbukaan proses dalam PBM meliputi sintesis dan integrasi dari sebuah proses belajar; dan j) PBM melibatkan evaluasi dan review pengalaman siswa dan proses belajar.

Rachmawati (dalam Ningsih, 2015: 27), kelebihan dari model pembelajaran berbasis masalah adalah sebagai berikut: a) meningkatkan motivasi belajar siswa melalui pengaplikasian konsep pada masalah;b) menjadikan siswa aktif dan belajar lebih mendalam (deep learners); c) memungkinkan siswa untuk membangun keterampilan dalam pemecahan masalah; d) meningkatkan pemahaman melalui dialog dan diskusi dalam kelompok; dan e) menjadi pembelajar yang mandiri.

Langkah-langkah pembelajaran berbasis masalah (Rusman, 2014: 243) yaitu: (1) menjelaskan tujuan pembelajaran, menjelaskan logistik yang diperlukan, dan memotivasi siswa terlibat pada aktivitas pemecahan masalah; (2) membantu siswa mendefinisikan dan mengorganisasikan tugas belajar yang berhubungan dengan masalah tersebut; (3) mendorong siswa untuk mengumpulkan informasi yang sesuai, melaksanakan eksperimen untuk mendapatkan penjelasan dan 
pemecahan masalah; (4) membantu siswa dalam merencanakan dan menyiapkan karya yang sesuai seperti laporan, model dan membantu mereka untuk berbagai tugas dengan temannya; (5) membantu siswa untuk melakukan refleksi atau evaluasi terhadap penyelidikan mereka dan proses yang mereka gunakan.

Konvensional dalam Kamus besar Bahasa Indonesia berarti: (1) berdasarkan konvensi (kesepakatan) umum (seperti adat, kebiasaan, kelaziman); (2) Tradisional. Sehingga pembelajaran konvensional yang dimaksud dalam penelitian ini adalah model pembelajaran langsung.

Menurut Meidawati (2014: 4), Model pembelajaran langsung merupakan model pembelajaran yang lebih berpusat pada guru dan lebih mengutamakan strategi pembelajaran efektif guna memperluas informasi materi ajar, pembelajaran ini mengkobinasikan berbagai metode di antaranya metode ceramah, tanya jawab, dan pemberian tugas. Hal senada juga dikemukaan oleh Diana (2014:15), dalam pembelajaran langsung guru bersifat sebagai teacher center atau berpusat pada guru karena dalam pembelajaran peran guru sangat dominan, maka guru dituntut untuk menjadi seorang model yang menarik bagi siswa. Sehingga model pembelajaran langsung dapat diartikan sebagai suatu model pembelajaran yang berpusat pada guru sebagai pemberi informasi utama dan siswa sebagai penerima informasi.

Pemahaman konsep matematis terdiri dari tiga kata yaitu pemahaman, konsep dan matematis. Menurut Muhrizal (2012: 19) pemahaman merupakan terjemahan dari istilah understanding yang diartikan sebagai penyerapan arti suatu materi yang dipelajari. Rusman (2014: 139) menyatakan bahwa pemahaman berarti penerimaan atau memahami informasi yang diperoleh dalam pembelajaran. Munurut kbbi online pemahaman adalah proses, cara, perbuatan memahami atau memahamkan. Berdasarkan beberapa pengertian di atas dan pendapat ahli, dapat disimpulkan pemahaman adalah suatu proses untuk mengerti suatu hal. Sedangkan pengertian konsep menurut kbbi online adalah ide atau pengertian yang diabstrakan dari peristiwa konkret dan menurut depdiknas dalam kesumawati (2008: 230) menyatakan bahwa konsep diartikan sebagai ide abstrak yang dapat digunakan unutk menggolongkan sekumpulan objek. Menurut Matematis menurut kbbi online merupakan sesuatu yang bersangkutan dengan matematika.

Pemahaman konsep matematis adalah suatu kemampuan untuk memahami ide abstrak untuk menggolongkan sekumpulan hal mengenai matematika. Pemahaman konsep matematis yang baik dapat menunjang pengetahuan selanjutnya hal ini disebabkan oleh dalam langkah-langkah mempelajari matematika harus memiliki dasar yang baik.

menurut Jihad dan Haris (2012: 149) adalah: (a) Kemampuan menyatakan ulang sebuah konsep; (b) Kemampuan mengklasifikasi objek menurut sifat-sifat tertentu sesuai dengan konsepnya; (c) Kemampuan memberi contoh dan bukan contoh; (d) Kemampuan menyajikan konsep dalam berbagai bentuk representasi matematis; (e) Kemampuan mengembangkan syarat perlu atau syarat cukup dari suatu konsep; (f) Kemampuan menggunakan, memanfaatkan dan memilih prosedur tertentu; dan (g) Kemampuan mengaplikasikan konsep atau algoritma ke pemecahan masalah.

Indikator pemahaman konsep matematis yang digunakan dalam penelitian ini adalah: (1) kemampuan menyatakan ulang sebuah konsep; (2) kemampuan mengklasifikassikan objek menurut sifat-sifat tertentu sesuai dengan konsepnya; (3) kemampuan menyajikan konsep dalam berbagai bentuk representasi matematis; (4) kemampuan menggunakan, memanfaatkan dan memilih prosedur tertentu; dan (5) kemampuan mengaplikasikan konsep atau algoritma ke pemecahan masalah.

\section{Metode}

Penelitian ini dilaksanakan di SMP Kesehatan Mandonga. Waktu Penelitian ini dilaksanakan pada Semester Ganjil bulan Oktober-November Tahun Ajaran 2017/2018. Populasi dalam penelitian ini adalah seluruh siswa kelas VIII di SMP Kesehatan Mandonga tahun ajaran 2017/2018, Gambaran populasi kelas VIII di SMP Kesehatan Mandonga diperlihatkan pada Tabel 1 berikut: 
Tabel 1

Populasi Siswa Kelas VIII dengan Nilai Rata-rata Tes Awal Pemahaman Konsep Matematis Mata Pelajaran Matematika Tahun Ajaran 2017/2018

\begin{tabular}{|c|c|c|}
\hline \multirow{2}{*}{ Kelas } & \multicolumn{2}{|c|}{ VIII } \\
\cline { 2 - 3 } & A & B \\
\hline Jumlah siswa & 35 & 34 \\
\hline Nilai Rata-Rata Tes Awal & 15.32 & 14.24 \\
\hline
\end{tabular}

Sampel dalam penelitian ini diambil dua random, sehingga diperoleh kelas $\mathrm{VIII}_{\mathrm{A}}$ sebagai kelas dari populasi. Penentuan sampel dalam penelitian ini dilakukan dengan menggunakan sampel sensus/sampel total yaitu mengambil sampel yang anggotanya adalah semua anggota. Berdasarkan tabel di atas, maka sampel yang ditetapkan adalah kelas $\mathrm{VIII}_{\mathrm{A}}$ dan kelas VIII $_{B}$. Selanjutnya penentuan kelas eksperimen dan kelas kontrol dipilih secara kelas eksperimen dan kelas $\mathrm{VIII}_{\mathrm{B}}$ sebagai kelas kontrol.

Variabel yang digunakan dalam penelitian ini terdiri dari variabel bebas dan variabel terikat. Variabel bebas disimbolkan dengan $\mathrm{X}$ dan variabel terikat disimbolkan dengan Y. Adapun desain yang digunakan digambarkan pada tabel 2 berikut :

Tabel 2

Desain Penelitian

\begin{tabular}{|c|c|c|}
\hline Kelompok & Perlakuan & Posttest \\
\hline Eksperimen (R) & $\mathrm{X}$ & $\mathrm{O}_{1}$ \\
\hline Kontrol (R) & & $\mathrm{O}_{2}$ \\
\hline
\end{tabular}

Keterangan :

$\mathrm{R}=$ Kelompok eksperimen dan kelompok kontrol siswa kelas VIII SMP Kesehatan Mandonga yang diambil secara sampel sensus/sampel total.

$\mathrm{X}=$ Perlakuan berupa pembelajaran dengan menggunakan model Pembelajaran Berbasis Masalah (PBM) pada kelompok eksperimen

$\mathrm{O}_{1}=$ Hasil posttest pada kelompok eksperimen setelah diberi pembelajaran dengan menggunakan model Pembelajaran Berbasis Masalah (PBM).

$\mathrm{O}_{2}=$ Hasil posttest pada kelompok kontrol yang diberipembelajaran seperti biasanya yaitu menggunakan model pembelajaran langsung.

Instrumen dalam penelitian ini mempunyai dua instrumen, yaitu berupa lembar observasi dan soal pemahaman konsep matematis siswa. Lembar observasi untuk mengukur tingkat aktivitas/partisipasi guru dan siswa dalam proses pembelajaran matematika dengan menggunakan mopembelajaran berbasis masalah. Lembar pengamatan yang dibuat terdiri dari beberapa aspek observasi yang bertujuan untuk mengontrol setiap tindakan/aktivitas yang dilakukan oleh guru dan siswa dalam kelas, selama proses pembelajaran berlangsung, persiapan materi pembelajaran, serta teknik yang digunakan guru dalam menerapkan pembelajaran berbasis masalah.

Tes digunakan untuk mengetahui seberapa besar kemampuan pemahaman konsep matematis siswa. Bentuk tes yang digunakan berupa Essay, yang disusun berdasarkan indikator pemahaman konsep matematis. Setiap butir soal disusun untuk mengukur indikator pemahaman konsep matematis tertentu.

Kemampuan pemahaman konsep matematis dalam penelitian ini adalah sebagai berikut:

1. kemampuan menyatakan ulang sebuah konsep.

2. kemampuan mengklasifikassikan objek menurut sifat-sifat tertentu sesuai dengan konsepnya.

3. kemampuan menyajikan konsep dalam berbagai bentuk representasi matematis.

4. kemampuan menggunakan, memanfaatkan dan memilih prosedur tertentu

5. kemampuan mengaplikasikan konsep atau algoritma ke pemecahan masalah.

Validitas instrumen dalam penelitian ini, peneliti menggunakan validitas konstruksi dan validitas empiris. Validitas konstruksi bertujuan 


\section{Jurnal Penelitian Pendididikan Matematika Volume 7 No.2 Mei 2019}

untuk menentukan berfungsi tidaknya suatu soal mengukur aspek yang hendak diukur (kemampuan pemahaman konsep matematis) berdasarkan kriteria yang telah ditentukan, dalam hal ini adalah kriteria materi, konstruk, dan bahasa. Tidak ada formula matematis untuk menghitung dan tidak ada cara untuk menunjukkan secara pasti. Hasil validasi tersebut ditentukan oleh penilaian para ahli yang terdiri dari (2) orang dosen pendidikan matematika FKIP UHO, (1) orang alumni mahasiswa matematika FKIP UHO dan dua (1) orang guru matematika di SMP Kesehatan Mandonga.

Penunjangan perhitungan validitas, maka butis soal tersebut dihitung dengan menggunakan rumus:

$V=\frac{\sum n_{i}\left|i-I_{0}\right|}{[N(c-1)]} \quad$ (Aiken dalam Riansyah, 2014: 42)

Keterangan:

$V \quad=$ Indeks validitas isi

$n_{i}=$ banyaknya nilai pada $i=$

$1,2,3,4, \& 5$

$i \quad=$ Angka yang diberikan penilai

$I_{0} \quad=$ Angka penilaian terendah

$N=$ Jumlah nilai yang diperoleh dari penilai

$c \quad=$ Angka penilaian tertinggi

Nilai $V$ terletak antara 0 dan 1 (valid

$\geq 0,6$ ). Hasil penelitian panelis terhadap validitas instrumen kemampuan pemahaman konsep matematis siswa dengan menggunakan rumus validitas dari Aiken, diperoleh kelima soal tersebut valid atau dapat digunakan untuk mengetahui alat ukur yang digunakan dapat mengukur apa yang seharusnya diukur.

Selanjutnya, dilakukan analisis Reliabilitas instrument. Instrument tes dikatakan reliabel apabila tes digunakan beberapa kali untuk mengukur objek yang sama, akan menghasilkan data yang sama. Untuk menguji reliabilitas tes dalam penelitian ini digunakan rumus berikut.

$r_{11}=\left[\frac{n}{n-1}\right]\left[1-\frac{s_{i}^{2}}{s_{t}^{2}}\right]$ (Ruseffendi dalam

Jihad,2012: 180)

Keterangan :

$$
\begin{array}{ll}
n & =\text { banyaknya butir soal } \\
s_{i}{ }^{2} & =\text { jumlah varians skor tiap item } \\
s_{t}{ }^{2} & =\text { varians skor total }
\end{array}
$$

Pengumpulan data dalam penelitian ini dilakukan dengan pemberian instrumen penelitian berupa tes kemampuan pemahaman konsep matematis yang berupa tes uraian sebanyak satu kali yaitu posttest pada kelas eksperimen dan kelas kontrol. Tes diberikan setelah kedua kelas (kelas eksperimen dan kelas kontrol) diberikan perlakuan yakni kelas eksperimen diajar dengan menggunakan model pembelajaran berbasis masalah sedangkan kelas kontrol diajar dengan model pembelajaran langsung.

Skor disesuaikan berdasarkan sistematika proses mengerjakannya, serta jenis aspek kemampuan pemahaman konsep matematika yang diberikan dalam soal. Selanjutnya hasil pekerjaan siswa dikumpulkan oleh peneliti untuk diperiksa dan diberi skor. Skor perolehan siswa dikonversi ke skala 100 dengan aturan : nilai perolehan siswa = $\frac{\text { skor perole han siswa }}{\text { skor maksimum }} \times 100$ nilai perolehan siswa tersebut merupakan data penelitian ini.

Teknik analisis data dalam penelitian ini menggunakan dua teknik analisis data yaitu analisis deskriptif dan inferensial. Analisis deksriptif merupakan analisis yang digunakan untuk menggambarkan keadaan sampel dalam bentuk persentase $(\%)$, rata-rata $(\bar{x})$, median (Me), modus (Mo), varians $\left(\mathrm{S}^{2}\right)$, standar deviasi $(\mathrm{S})$, nilai maksimum $\left(\mathrm{X}_{\max }\right)$, dan nilai minimum $\left(\mathrm{X}_{\min }\right)$, skweness dan kurtosis. Analisis inferensial dimaksudkan untuk menguji hipotesis penelitian, yang dilakukan dengan uji normalitas dan uji homogenitas sebagai uji prasyarat untuk melakukan uji hipotesis.

\section{Hasil}

Berdasarkan hasil observasi terhadap pelaksanaan pembelajaran matematika dengan menggunakan PBM pada materi sistem persamaan linear dua variabel (SPLDV) yang dilakukan oleh peneliti pada pertemuan pertama sudah dikatakan cukup baik sebab tingkat keberhasilannya adalah 57,69\%.Pada pertemuan ini, peneliti menyesuaikan kondisi kelas dengan model pembelajaran yang akan digunakan, dimana siswa juga masih dalam tahap penyesuain dengan teman kelompok, model pembelajaran yang digunakan sehingga pada pertemuan ini masih banyak aktivitas pembelajaran yang direncanakan oleh peneliti 
tidak terlaksana dikarenakan waktu pembelajaran yang telah usai.

Pada pertemuan kedua, keterlaksanaan pembelajaran berada pada tingkat keberhasilannya $69,23 \%$ hal ini mengalami peningkatan yang cukup baik dari pertemuan sebelumnya walaupun masih dalam kriteria cukup baik. Pada pertemuan ini, masih terdapat kekurangan dalam melaksanakan pembelajaran, misalnya pada kegiatan pendahuluan peneliti lupa menyampaikan model pembelajaran yang digunakan, indikator pembelajaran dan menjelaskan logistik (alat tulis, buku paket, dsb). Selanjutnya pada kegiatan inti, peneliti tidak menjelaskan pengerjaan lembar kerja siswa (LKS), memberi dorongan kepada siswa untuk mengumpulkan informasi yang diperlukan, membantu siswa merancang dan menyiapkan hasil kerja kelompok yang akan dipresentasikan didepan kelas, mendorong siswa lain untuk saling memberi tanggapan terhadap jawaban yang di presentasikan didepan kelas dan tidak memberi penghargaan terhadap kelompok yang kinerjanya bagus. Sedangkan, pada kegiatan penutup peneliti telah malaksanakan semua aktivitas yang telah di rencanakan.

Keterlaksanan rencana pembelajaran pada pertemuan ketiga dan keempat mengalami peningkatan yang baik, hal ini terlihat pada tingkat keberhasilannya masing-masing adalah $76,92 \%$ dan $88,77 \%$ dan masuk dalam kriteria baik. Namun, pada pertemuan kelima mengalami penurunan sebesar 73,08\%hal ini disebabkan oleh terjadinya hal-hal yang tidak diinginkan yaitu terdapat seorang siswi sakit dan perlu diberitahukan ke orang tuanya. Kemudian pada saat pertemuan keenam mengalami peningkatan yang baik dengan tingkat keberhasilannya adalah 92,31\% di karenakan siswa sudah mampu menyesuaikan diri dengan model pembelajaran yang diterapkan oleh peneliti.

Berdasarkan observasi aktivitas siswa, pada pertemuan pertama tingkat ketercapaian aktivitas siswa dalam pembelajaran adalah $62,04 \%$ yang berarti keaktifan siswa pada pertemuan pertama cukup baik.Namun pada pertemuan pertama ini siswa masih dalam tahap penyesuaian diri terhadap model pembelajaran yang digunakan berakibat masih kurang keseriusan dalam belajar, acuh tak acuh dan cenderung saling berharap kepada temannya dalam mengerjakan tugas berkelompok sehinnga terjadi kurangnya kerja sama antar anggota kelompok.

Pertemuan kedua, keaktifan siswa terjadi peningkatan yang cukup baik dengan tingkat ketercapaian aktivitas siswa dalam pembelajaran sebesar $66,67 \%$, hal ini disebabkan oleh siswa mulai menggetahui tahapan-tahapan model pembelajaran yang digunakan dan siswa pula mulai aktif dalam melaksanakan proses pembelajaran. Hal ini juga terlihat pada pertemuan ketiga dan keempat yang mengalami peningkatan yang baik dengan tingkat ketercapaian aktivitas siswa dalam pembelajaran masing-masing menjadi $75,93 \%$ dan 83,33\%, ketercapaian pada pertemuan ketiga masuk dalam kategori baik sedangkan pertemuan keempat masuk dalam kategori baik. Tetapi, pada pertemuan kelima terjadi penurunan tingkat ketercapaian aktivitas siswa dalam pembelajaran. Tingkat ketercapiannya adalah 74,07\%, hal ini disebabkan oleh masih terdapat siswa yang sakit dan mendapat respon yang berlebihan dari teman-teman kelas sehingga memuat suasana kelas menjadi tidak kondusif. Selanjutnya pada pertemuan keenam tingkat ketercapian aktivitas siswa dalam pembelajaran mengalami peningkatan yang baik menjadi92,59\%. Hal ini menunjukan bahwa siswa sudah bisa melakukan pembelajaran lebih baik menggunakan model pembelajaran berbasis masalah. Berdasarkan uraian tersebut, dapat disimpulkan bahwa siswa memerlukan waktu untuk beradaptasi dalam menggunakan model pembelajaran yang baru diterapkan agar mendapat tingkat keberhasilan yang baik.

Hasil analisis deskriptif nilai posttest siswa setelah diterapkan pembelajaran berbasis masalah pada kelas eksperimen dan model pembelajaran langsung pada kelas kontrol. Untuk lebih jelas, maka deskripsi nilai posttest kelas eksperimen dan kelas kontrol disajikan pada Tabel 3. 
Tabel 3

Hasil Data Posttest Pemahaman Konsep Matematis Siswa

Kelas Eksperimen dan Kelas Kontrol

\begin{tabular}{|l|c|c|}
\hline & Posttest Kelas Eksperimen & $\begin{array}{c}\text { Posttest Kelas } \\
\text { Kontrol }\end{array}$ \\
\hline Rata-rata (Mean) & 55.88 & 45.91 \\
\hline Nilai tengah (Median) & 52.5 & 45 \\
\hline Nilai yang sering mencul (Modus) & 50 & 45 \\
\hline Standar deviasi & 13.05 & 16.93 \\
\hline Nilai varians & 170.41 & 286.65 \\
\hline Nilai tertinggi (Maks) & 80 & 85 \\
\hline Nilai terendah (Min) & 35 & 10 \\
\hline Kemiringan (Skewness) & 0.51 & -0.29 \\
\hline
\end{tabular}

Berdasarkan Tabel 3 di atas terlihat bahwa kemampuan pemahaman konsep matematis pada kelas eksperimen diperoleh nilai terendah 35 sedangkan nilai tertinggi adalah 80 , nilai rata-rata 55,88 , nilai standar deviasi adalah 13,05 dan varians 170,41. Sedangkan kelas kontrol diperoleh diperoleh nilai terendah 10

Tabel 4

Distribusi Data Posttest Menggunakan Model Pembelajaran Berbasis Masalah (PBM) dan Menggunakan Model Pembelajaran Konvensional

\begin{tabular}{|c|c|c|c|c|c|c|}
\hline \multirow{2}{*}{ No. } & \multirow{2}{*}{ Nilai } & \multirow{2}{*}{ Tingkat } & \multicolumn{2}{c|}{$\begin{array}{c}\text { Model Pembelajaran Berbasis } \\
\text { Masalah (PBM) }\end{array}$} & \multicolumn{2}{c|}{$\begin{array}{c}\text { Model pembelajaran } \\
\text { Konvensional }\end{array}$} \\
\cline { 4 - 7 } & & & Frekuensi & Presentase $(\%)$ & Frekuensi & $\begin{array}{c}\text { Presentase } \\
(\%)\end{array}$ \\
\hline 1 & $0,00 \leq Y \leq 25$ & Kurang & 0 & 0 & 6 & 18,18 \\
\hline 2 & $25<Y \leq 50$ & Cukup & 17 & 50 & 16 & 48,48 \\
\hline 3 & $50<Y \leq 75$ & Baik & 14 & 41,18 & 10 & 30.3 \\
\hline 4 & $75<Y \leq 100$ & $\begin{array}{c}\text { Sangat } \\
\text { Baik }\end{array}$ & 3 & 8,82 & 1 & 3,03 \\
\hline \multicolumn{3}{|c|}{ Jumlah } & 34 & & 33 & \\
\hline
\end{tabular}

Berdasarkan Tabel 4 di atas terlihat bahwa pada kelas eksperimen ada 17 orang yang berada pada kategori cukup, 14 orang pada kategori baik dan 3 orang masuk pada kategori baik. Sedangkan pada kelas kontrol ada 6 orang masuk kategori kurang, 16 orang masuk kategori cukup, 10 orang masuk kategori baik dan 1 sedangkan nilai tertinggi adalah 85 , nilai ratarata 45,91 , nilai standar deviasi adalah 16,93 dan varians 286,65 . Adapun distribusi frekuensi nilai posttest pemahaman konsep matematis siswa kedua kelas baik kelas eksperimen maupun kelas kontrol dapat dilihat pada Tabel 4 berikut. 


\section{Distribusi Data Posttest}

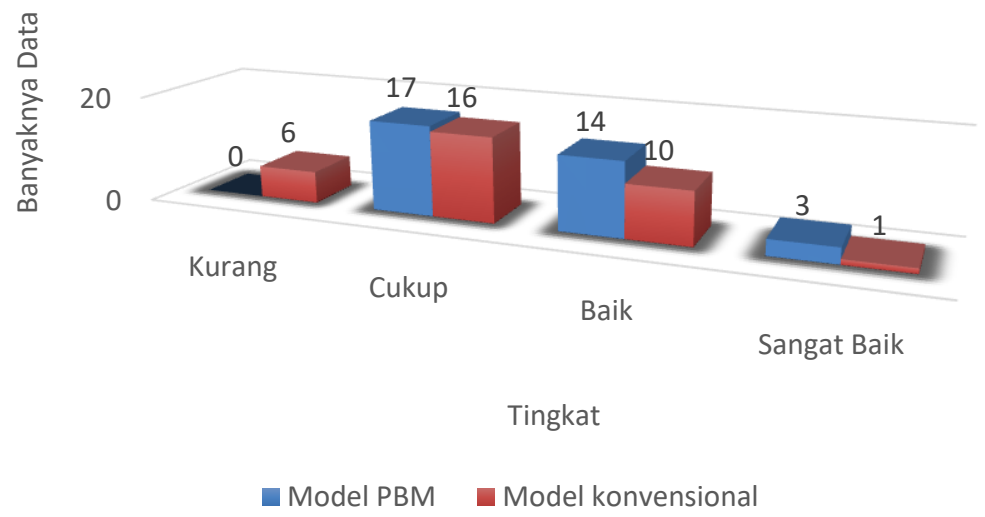

Gambar 1. Distribusi Data Posttest

Berdasarkan Gambar 1 terlihat bahwa siswa kelas eksperimen pada tingkat pemahaman konsep matematis kategori kurang tidak ada, cukup 17 orang, baik 14 orang dan sangat baik 3 orang. Sedangkan siswa kelas kontrol pada tingkat pemahaman konsep matematis kategori kurang terdapat 6 orang,

Tabel 5

Hasil Analisis Statistik Uji Normalitas Data Posttest Pemahaman Konsep Matematis Siswa Kelas Eksperimen dan Kelas Kontrol

\begin{tabular}{|l|l|l|l|}
\hline \multicolumn{2}{|l|}{} & Eksperimen & Kontrol \\
\hline $\mathrm{N}$ & Rata-rata & 34 & 33 \\
\hline \multirow{2}{*}{ Parameter Normal } & a,b & 55.88 & 45.91 \\
\cline { 2 - 4 } & Standar deviasi & 13.054 & 16.931 \\
\hline \multirow{3}{*}{ Selisih Paling Ekstrim } & Mutlak & .174 & .176 \\
\cline { 2 - 4 } & Positif & .174 & .081 \\
\cline { 2 - 4 } & Negatif & -.105 & -.176 \\
\hline Kolmogorov-Smirnov Z & 1.015 & 1.009 \\
\hline Asymp. Sig. (2-tailed) & .255 & .261 \\
\hline
\end{tabular}

a. Uji distribusi normal

b. Perhitungan dari data

Pada Tabel 6 di atas, dapat dilihat bahwa nilai Asymp. Sig. (2-tailed) untuk kelas eksperimen adalah $0,255>\alpha$ (dengan $\alpha=$ $0,05)$, maka $\mathrm{H}_{0}$ diterima. Sedangkan untuk kelas kontrol adalah 0,261 $>\alpha$ (dengan $\alpha=0,05$ ), maka $\mathrm{H}_{0}$ diterima. Sehinnga, dapat disimpulkan bahwa kelas eksperimen dan kelas kontrol samasama berdistribusi normal. cukup 16 orang, baik 10 orang dan sangat baik 1 orang. Hasil analisis tersebut dapat disimpulkan bahwa secara klasikal tingkat pemahaman konsep matematis siswa untuk kelas eksperimen lebih baik ketimbang kelas kontrol pada materi sistem persamaan linear dua variabel (SPLDV).
Uji homogenitas digunakan untuk mengetahui apakah data mempunyai varians yang sama (homogen) atau tidak. Untuk menguji apakah data mempunyai varians yang sama atau tidak digunakan statistik uji $\mathrm{F}_{\text {hitung }}$ seperti yang disajikan pada tabel 6 .

sama berdistribusi normal. 
Tabel 6

Hasil Analisis Statistik Uji Homogenitas Varians Data Posttest

Pemahaman Konsep Matematis Siswa

\begin{tabular}{|c|c|c|}
\hline \multirow{2}{*}{$\begin{array}{l}\text { B } \\
\text { erdasark } \\
\text { an Tabel }\end{array}$} & Jumlah siswa Kelas Eksperimen & 34 \\
\hline & Jumlah Siswa Kelas Kontrol & 33 \\
\hline \multirow{2}{*}{6 atas, } & DK Pembilang $\left(n_{1}\right)$ & 32 \\
\hline & Dk Penyebut $\left(n_{2}\right)$ & 33 \\
\hline \multirow{3}{*}{$\begin{array}{l}\text { atas, } \\
\text { dapat } \\
\text { dilihat } \\
\text { bahwa } \\
\text { nilai }\end{array}$} & $\alpha$ & 0.05 \\
\hline & Varians Kelas Eksperimen (Varians kecil) & 170.4099822 \\
\hline & Varians kelas Kontrol (Varians besar) & 286.6477273 \\
\hline \multirow{2}{*}{$\begin{array}{l}F_{\text {hitung }} \\
\text { adalah }\end{array}$} & F hitung & 1.682106 \\
\hline & $F$ tabel & 1,793429 \\
\hline
\end{tabular}

Rata-

rata

kemamp

uan

pemaha

man

konsep

matemti

s siswa

yang

diajar

$\mathrm{F}_{\text {Tabel }} \quad$ (dengan $\quad \mathrm{F}_{\text {tabel }}=\mathrm{F}\left(\alpha,\left(n_{1}, n_{2}\right)\right)=$ 1,793429), maka $\mathrm{H}_{0}$ diterima. Sehingga dapat disimpulkan bahwa kelas eksperimen dan kelas kontrol memiliki varians yang sama. Ini berarti sebaran data Posttest kedua kelas yang diajar mengunakan model pembelajaran berbasis masalah dan model pembelajaran langsung memiliki varians yang sama (homogen).

Selanjutnya mengetahui perbedaan pengaruh penggunaan pembelajaran berbasis masalah dan model pembelajaran konvensional terhadap pemahaman konsep matematis siswa, digunakan uji $\mathrm{T}$ sampel independen. Uji ini digunakan untuk mengetahui ada atau tidaknya perbedaan pengaruh penggunaan pembelajaran berbasis masalah dan model pembelajaran konvensional terhadap pemahaman konsep matematis siswa. Rumus hipotesis statistik yang diuji adalah:

$\mathrm{H}_{0}: \mu_{1} \leq \mu_{2}$ lawan $\mathrm{H}_{1}: \mu_{1}>\mu_{2}$

Keterangan:

dengan model Pembelajaran Berbasis Masalah.

$\mu_{2}$ : Rata-rata kemampuan pemahaman konsep matematis siswa yang diajar dengan model pembelajaran langsung.

$\mathrm{H}_{0}$ : Rata-rata kemampuan pemahaman konsep matematis siswa yang diajar dengan model pembelajaran berbasis masalah tidak lebih tinggi dibandingkan dengan rata-rata kemampuan pemahaman konsep matematis siswa yang diajar dengan model pembelajaran langsung.

$\mathrm{H}_{1}$ : Rata-rata kemampuan pemahaman konsep matematis siswa yang diajar dengan model pembelajaran berbasis masalah lebih tinggi dibandingkan dengan rata-rata kemampuan pemahaman konsep matematis siswa yang diajar dengan model pembelajaran langsung.

Hasil pengujiannya dapat dilihat pada Tabel 7.

Tabel 7

Hasil Analisis Statistik Uji Hipotesis (Uji-t) Pemahaman Konsep Matematis

\begin{tabular}{|l|l|c|c|c|r|r|}
\hline \multicolumn{2}{|c|}{} & \multicolumn{3}{|c|}{$\begin{array}{l}\text { Uji leneve untuk } \\
\text { kesamaan varians }\end{array}$} & \multicolumn{3}{|c|}{ Uji t untuk kesamaan rata-rata } \\
\cline { 3 - 7 } & F & sig. & T & Df & $\begin{array}{c}\text { Signifikansi } \\
\text { (dua arah) }\end{array}$ \\
\hline $\begin{array}{l}\text { Pemahaman } \\
\begin{array}{l}\text { Konsep } \\
\text { matematis } \\
\text { Siswa }\end{array}\end{array}$ & $\begin{array}{l}\text { Asumsi varians } \\
\text { sama }\end{array}$ & .710 & .402 & 2.705 & 65 & .009 \\
\cline { 2 - 7 } & $\begin{array}{l}\text { Asumsi Varians } \\
\text { tidak sama }\end{array}$ & & & 2.695 & 60.160 & .009 \\
\hline
\end{tabular}

Berdasarkan Tabel 7, terlihat bahwa nilai $t_{\text {hitung }}$ adalah $2,705>t_{\text {tabel }}$ (dengan $\mathrm{t}_{(34+33-2}$, $0,05)=1,669)$, maka $\mathrm{H}_{0}$ ditolak, artinya rata-rata kemampuan pemahaman konsep matematis siswa yang diajar dengan model pembelajaran berbasis masalah lebih tinggi dibandingkan 
dengan rata-rata kemampuan pemahaman konsep matematis siswa yang diajar dengan model pembelajaran langsung. Sehingga dapat disimpulkan bahwa ada pengaruh yang signifikan penerapan model pembelajaran berbasis masalah terhadap kemampuan pemahaman konsep matematis siswa.

\section{Pembahasan}

Total pertemuan ini sebanyak 7 kali yaitu 6 kali pertemuan dalam proses pembelajaran baik yang diajar menggunakan model pembelajaran berbasis masalah (PBM) sebagai kelas eksperimen dan diajar menggunakan model pembelajaran konvensional sebagai kelas kontrol dengan menggunakan materi yang sama yaitu sistem persamaan linear dua variabel (SPLDV) dan 1 kali pertemuan diakhir untuk melaksanakan tes pemahaman konsep matematis siswa atau dalam artian posttestpemahaman konsep matematis siswa. Pembelajaran yang dilaksanakan pada kelas eksperimen memiliki 5 tahapan yakni: orientasi siswa pada masalah, mengorganisasi siswa untuk belajar, membimbing pengalaman individu/kelompok, mengembangkan dan menyajikan hasil karya, dan Menganalisis dan mengevaluasi proses pemecahan masalah.

Pelaksanaan proses pembelajaan di kelas eksperimen memiliki 3 kegiatan utama yaitu: kegiatan pendahuluan, kegiatan inti dan kegiatan penutup. Kegiatan pendahuluan mencakup: penyampaian model pembelajaran, penyampaian indokator, penyampaian tujuan, melakukan apersepai dan pemberian motivasi. Kegiatan inti mencakup: pembagian kelompok yang terdiri dari 5-7 orang, penjelasan mengenai materi beserta contoh, pemberian lembar kerja siswa (LKS) pada setiap kelompok dan mempresentasikan hasil kerja kelompok di depan kelas. Kegiatan penutup mencakup: merangkum materi pembelajaran bersama-sama, pembrian tugas dan menginformasikan materi pembelajaran selanjutnya.

Pada pertemuan pertama pada kelas eksperimen aktifitas pembelajaran yang dilakukan oleh guru masuk dalam kategori cukup baik secara umum hal ini disebabkan oleh peneliti baru dalam proses penyesuaian diri dengan kondisi kelas dan model pembelajaran berbasis masalah (PBM) yang digunakan dalam proses pembelajaran. Penggunaan model pembelajaran berbasis masalah dalam prosesnya pada pertemuan pertama masih banyak aktivitas pembelajaran yang direncanakan tidak terlaksana dikarenakan lupa dan waktu pembelajaran telah usai.

Secara khusus pada kegiatan pendahuluan peneliti sudah cukup baik dalam melaksanakan rencana pembelajaran hanya pada kegiatan ini peneliti lupa untuk menjelaskan logistic yang diperlukan dalam pembelajaran dan memotivasi siswa. Pada kegiatan ini setelah peneliti membentuk kelompok, menjelaskan materi dan setelah peneliti memberikan contoh soal peneliti langsung memberikan lembar kerja siswa (LKS) pada setiap kelompok yang telah dibentuk, seharusnya sebelum itu peneliti harus menanyakan kembali apakah ada hal yang kurang jelas dalam penyampaian penjelasan materi. Selanjutnya peneliti juga lupa untuk menjelaskan petunjuk pengerjaan LKS dan memberikan dorongan kepada siswa untuk mengumpulkan informasi yg diperlukan. Peneliti hanya melakukan pengamatan dalam proses pengerjaan LKS dan membimbing siswa yang mengalami kesulitan dalam pengerjaan LKS, peneliti tidak membantu siswa dalam proses merangcang hasil kerja kelompok dan hanya langsung mendengarkan laporan hasil pengerjaan LKS. Selanjutnya, peneliti tidak memberi kesempatan kepada kelompok lain untuk menanggapi hasil kerja kelompok yang mempersentasikan hasil kerja kelompok, peneliti langsung mengambil alih dengan memandu pengambilan dalam pengerjaan LKS hal ini disebabkan karena waktu pembelajaran dikelas sudah hamper usai. Pada kegiatan penutup peneliti hanya mengucapkan salam penutup tanpa memandu siswa dalam membuat kesimpulan dari materi pembelajaran, tidak memberikan pekerjaan rumah (PR) dan tidak menyampaikan materi selanjutnya.

Sebaiknya sebelum melaksanakan proses pembelajaran di kelas peneliti sudah harus mempersiapkan nama-nama kelompok dan menyuruh siswa untuk sebelum masuk dalam proses pembelajaran siswa telah berada pada membentuk kelompoknya agar pada saat proses pembelajaran peneliti tidak terlalu banyak menghabiskan waktu pembelajaran hanya untuk memandu siswa bergabung pada kelompokmya dan peneliti juga harus membaca kembali rancangan pembelajaran yang telah disiapkan sebelum masuk kelas agar pada saat proses pembelajaran peneliti tidak banyak mengalami kelupaan langkah-langkah 
pembelajaran yang telah disusun dan juga pengunaan waktu pembelajaran digunakan secara seefisien mungkin agar pada saat proses pembelajaran mendapatkan hasil yang diinginkan. Pada setiap pertemuan selanjutnya peneliti sudah mulai terbiasa dengan kondisi kelas, model pembelajaran yang digunakan dan melakukan perbaikan-perbaikan dalam mengelola kelas, setelah melakukan hal tersebut aktifitas pembelajaran yang dilakukan oleh guru mengalami peningkatan yang baik secara persentase.

Data aktivitas siswa, pada petemuan pertama kelas eksperimen yang menggunakan model pembelajaran berbasis maslah (PBM) aktivitas siswa masuk dalam kategori cukup baik, secara umum hal ini disebabkan oleh belum terbiasanya siswa dalam melakukan proses pembelajaran yang menggunakan model pembelajaran berbasis masalah (PBM) dan siswa terlihat pasif dalam melaksanakan proses pembelajaran. Pada penggunaan model PBM siswa dituntut untuk lebih aktif dalam proses pembelajaran dan guru hanya sebagai fasilitator sehingga dibutuhkan kerja sama yang baik, perhatian dan motivasi dari seluruh siswa agar mendapatkan hasil sesuai yang diinginkan. Peneliti seharusnya dapat memotivasi siswa agar motivasi belajar siswa meningkat dan tidak terlihat pasif dalam proses pembelajaran.

Persentase keaktifitas siswa disetiap pertemuan selalu meningkat, disebabkan oleh murid sudah mulai terbiasa menggunakan model pembelajaran yang digunakan dan sudah mulai termotivasi dalam mengikuti kegiatan proses pemblajaran dan sudah mulai terlihat aktif dalam pembelajaran, walaupun pada pertemuan kelima mengalami penurunan disebabkan dengan hal-hal yang tak terdunga tetapi pada saat pertemuan keenam mengalami peningkatan yang baik. Pada pertemuan kelima hal yang menyebabkan penurunan persentase keterlaksanan aktivitas pembelajaran yang dilakukan siswa adalah terdapat seorang siswa yang sakit dan ditanggapi secara berlebihan oleh siswa-siswa lain dan membuat gaduh dalam kelas sehingga butuh waktu dalam proses mengkondisikan kelas agar siap kembali dalam mengikuti proses pembelajaran.

Data yang digunakan dalam penelitian ini diperoleh darihasil tes pemahaman konsep matematis siswa pada kelas eksperimen dan pada kelas kontrol dengan materi sistem persamaan linear dua variabel (SPLDV) setelah diberikan perlakuan. Adapun indikator pemahaman konsep yang digunakan dalam penelitian ini yaitu: (1) kemampuan menyatakan ulang sebuah konsep, (2) kemampuan mengklasifikasikan objek menurut sifat-sifat tertentu sesuai dengan konsepnya, (3) kemampuan menyajikan konsep dalam berbagai bentuk representasi matematis, (4) kemampuan menggunakan, memanfaatkan dan memilih prosedur tertentu, dan (5) kemampuan mengaplikasikan konsep atau algoritma ke pemecahan masalah.Tes pemahaman konsep matematis ini telah melaui uji validitas dan uji reliabilitas dimana uji validitas menggunakan uji panelis dan untuk uji reliabilitas menggunakan perhitunggan Alpha Croanbach dengan bantuan SPSS.

Berdasarkan rerata skor pada indikator pertama terlihat bahwa pada rerata skor kelas eksperimen lebih baik ketimbang rerata skor kelas kontrol, hal ini disebabkan oleh pada kelas eksperimen siswa lebih teliti dalam membaca soal sedangkan kelas kontrol kurang teliti dalam membaca soal terlihat dari jawaban siswa yang salah dalam mengartikan soalnya dimaksud yang seharusrnya ditanyakan pengertian sistem persamaan linear dua variabel (SPLDV) tetapi siswa di kelas kontrol banyak yang menjawab persamaan linear dua variabel (PLDV). Pada indikator kedua mengenai kemampuan mengklasifikasikan objek menurut sifat-sifat tertentu sesuai dengan konsepnya, rerata skor kelas eksperimen lebih baik ketimbang rerata skor kelas kontrol, hal ini disebabkan oleh pada kelas kontol siswa banyak yang salah mengartikan maksud dari soal yang berbentuk a,b,c yang bukan merupakan pilihan ganda mereka memilih salah satu untuk menjelaskan obyek yang diminta, begitu pula untuk kelas eksperimen walaupun rerata skor kelas eksperimen lebih baik dari rerata skor kals kontrol. Pada indikator ketiga mengenai kemampuan menyajikan konsep dalam berbagai bentuk representasi matematis, siswa pada kedua kelas sudah cukup mahir dalam mengerjakan masalah ini hanya pada perolehan rerata skor kelas eksperimen lebih baik dari rerata skor kelas kontrol, hal ini disebabkan oleh pada kelas eksperimen digunakan lembar kerja siswa dimana lembar kerja siswa tersebut banyak melatih siswa pada kelas eksperimen dalam memodelkan soal cerita kedalam model matematika. 
Berbeda pada indikator pertema, kedua dan ketiga dimana rerata skor kelas eksperimen lebih baik dari kelas kontrol, pada indikator keempat dan kelima rerata skor kelas kontrol lebih baik dari rerata skor kelas eksperimen. Pada indikator keempat mengenai kemampuan menggunakan, memanfaatkan dan memilih prosedur tertentu, banyak siswa siswa di kelas eksperimen maupun di kelas kontrol yang tidak menjawab. Sedangkan pada indikator kelima mengenai kemampuan mengaplikasikan konsep atau algoritma ke pemecahan masalah, siswabanyak siswa siswa di kelas eksperimen maupun di kelas kontrol yang tidak menjawab.

Pengkatagorian nilai rata-rata pada kelas eksperimen berada dalam kategori baik sedangkan pada kelas kontrol berada dalam kategori cukup. Varians kelas eksperimen lebih kecil dari pada kelas kontrol, hal ini menyebabkan kelas kontrol lebih heterogen (beragam) dalam distribusi nilai dari kelas eksperimen. Bardasarkan hasil analisis data dengan bantuan SPSS dan Microsoft Excel pada tabel 5 dan 6 terlihat bahwa data pada kelas eksperimen dan kontrol sama-sama berdistribusi normal dan kedua data tersebut homogen. Pada tabel 7 menggunakan uji-t dengan bantuan SPSS terlihat bahwa $t_{\text {hitung }}$ lebih besar dari $t_{\text {tabelyang }}$ berarti $\mathrm{H}_{0}$ ditolak sehingga dapat disimpulkan bahwa terdapat pengaruh yang signifikan penggunaan model pembelajaran berbasis masalah (PBM) terhadap kemampuan pemahaman konsep matematis siswa kelas VIII SMP kesehatan mandonga.

\section{Simpulan dan Saran}

\section{Simpulan}

Berdasarkan hasil penelitian maka dapat disimpulkan sebagai berikut:

1. Proses pembelajaran matematika dengan menggunakan modelpembelajaran berbasis masalah (PBM) pada siswa kelas VIII SMP Kesehatan mandongatergolong baik. Hal ini ditunjukkan dengan persentase keterlaksanaan pembelajaran oleh guru pada 6 kali pertemuan berturut-turut adalah $57,69 \%, \quad 69,23 \%, \quad 76,92 \%, \quad 88,77 \%$, $73,08 \%$ dan $92,31 \%$. Demikian pula dengan persentase keaktifan siswa pada 6kali pertemuan berturut-turut adalah $62,04 \%$, $66,67 \%$ $75,93 \%, 83,33 \%, 74,07$ dan $92,59 \%$.
2. Pemahaman konsep matematis siswa kelas VIII SMP kesehatan mandonga yang diajar menggunakan model pembelajaran berbasis masalah (PBM) pada materi sistem persamaan linear dua variabel (SPLDV) memiliki nilai rata-rata 55,88 , median 52,5 , modus 50 , nilai maksimum 80 , nilai minimum 35 dan varians 170,41 dengan jumlah siswa 34 orang. Sedangkan pada tingkat pengkatagorian, siswa yang masuk kategori cukup sebanyak 17 orang, kategori baik 14 orang dan kategori sangat baik 3 orang, serta data nilai posttest pemahaman konsep matematis siswa berdistribusi normal.

3. Pemahaman konsep matematis siswa kelas VIII SMP kesehatan mandonga yang diajar menggunakan model pembelajaran konvensional pada materi sistem persamaan linear dua variabel (SPLDV) memiliki nilai rata-rata 45,91 , median 45 , modus 45 , nilai maksimum 85, nilai minimum 10 dan varians 286,65 dengan jumlah siswa 33 orang. Sedangkan pada tingkat pengkatagorian, siswa yang masuk kategori kurang sebanyak 6 orang, cukup sebanyak 16 orang, kategori baik 10 orang dan kategori sangat baik 1 orang, serta data nilai posttest pemahaman konsep matematis siswa berdistribusi normal.

4. Berdasarkan hasil uji t, menunjukkan bahwa rata-rata kemampuan pemahaman konsep matematis siswa yang diajar dengan model pembelajaran berbasis masalah lebih tinggi dibandingkan dengan rata-rata kemampuan pemahaman konsep matematis siswa yang diajar dengan model pembelajaran langsung, hal ini disebabkan oleh nilai $\mathrm{t}_{\text {hitung }}$ adalah 2,705>t $\mathrm{t}_{\text {tabel }}$ (dengan $\left.\left.\mathrm{t}_{(34+33-2}, \quad 0,05\right)=1,669\right)$. Sehingga dapat dikatakan bahwa ada pengarug yang signifikan penggunaan model pembelajaran berbasis masalah terhadap kemampuan pemahaman konsep matematis siswa kelas VIII SMP Kesehatan Mandongan.

\section{Saran}

Berdasarkan kesimpulan di atas, saran yang dapat diberikan adalah sebagai berikut :

1. Guru sekiranya dapat menggunakan model pembelajaran berbasis masalah (PBM)sebagai salah satu alternatif model 
pembelajaran untuk meningkatkan pemahaman konsep matematis siswa, karena model ini bisa membuat siswa lebih aktif dalam proses pembelajaran dan guru berperan sebagai fasilitator bagi siswa.

2. Perangkat pembelajaran dan tes pemahaman konsep matematis siswa yang terdapat pada penelitian ini, dapat digunakan sebagai acuan bagi guru SMP jika menerapkan model pembelajaran berbasis masalah (PBM) di kelas dengan menyesuaikan materi yang diajarkan.

3. Karena adanya beberapa keterbatasan peneliti dalam pelaksanaan penelitian, maka disarankan untuk penelitian lanjutan dari penelitian ini. Misalnya, dengan cakupan materi yang lebih luas atau mencoba memilih menggunakan penelitian kualitatif untuk penerapan model pembelajaran berbasis masalah (PBM).

\section{Daftar Pustaka}

Diana. (2014). Penerapan Model Pembelajaran langsung menggunakan Garis bilangan untuk Meningkatkan Kemampuan Siswa dalam menyelesaikan soal Penjumlahan dan pengurangan Bilangan Bulat Di Kelas VII SMP Negeri 3 Banawa. JurnalElktronik Pendidikan MatematikaTadulako, Vol. 2(1):13-22.

Fathurrohman, M. (2015). Model-Model Pembelajaran Inovatif. Ar-Ruzz Media. Yogyakarta.

Jihad, A \& Haris, A. (2012). Evaluasi Pembelajaran. Multi Pressindo. Yogyakarta.

Kesumawati, N.( 2018). Pemahaman Konsep Matematik Dalam Pembelajaran Matematika. Semnas Matematika dan Pendidian Matematika 2008: Universitas PGRI Palembang.

Meidawati, Y. (2014). Pengaruh Pendekatan Pembelajaran Inkuiri Tebimbing Terhadap Peningkatan Kemampuan Pemecahan Masalah Matematis Siswa SMP. Jurnal Pendidikan dan Keguruan, Vol. 1 (2), 2014.

Muhrizal, A. (2012). Pemahaman Konsep Matematis dan Model Pembelajaran
Quantum teaching. Jurnal Pendidikan Matematika. vol.1 no.1.(2012).

Riansyah, F. (2014). Peningkatan Kemampuan Berpikir Kreatif Matematik Siswa Kelas XI IPA SMA Negeri 5 Kendari dengan Menggunakan Pendekatan Pembelajaran Open-Ended (Studi Eksperimen Tahun Ajaran 2013/2014). Kendari. Universitas Halu Oleo. Skripsi.

Rusman. (2014). Model-model Pembelajaran Mengembangkan Profesionalisme Guru. Rajawali Pers. Jakarta.

Sagala, S. (2014). Konsep dan Makna Pembelajaran. Bandung. Alfabeta.

Sugiyono. (2011). Metode Penelitian Kuantitatif, Kualitatif dan $R \& D$. Alfabeta. Bandung. 